\title{
Nutraceutical value added sea weed - Gracilaria corticata var. cylindrica from thoothukudi
}

\begin{abstract}
The marine macroalgae represent one of the major components of coastal ecosystem and are of fundamental ecological importance as primary producers in the coastal regions of ocean waters. Of the total marine macrophytic algae, red algae with most ancient eukaryotic lineage are diverse in their habitats and cellular organizations, and comprise the highest number of species diversity over. The proximate composition, dietary fiber, element and amino acid contents of the red seaweed-Gracilaria corticata var. cylindrica and was collected from Thoothukudi to evaluate their potential nutritional value. The protein content was significantly higher $(\mathrm{P}<0.05)$. Lipid, ash, total dietary fiber (TDF), soluble dietary fiber (SDF) and insoluble dietary fiber were present in substantial level. Qualitative analysis revealed a pool of phytochemicals in various extarcts and more in methanolic extract. Total phenol, flavonoids and terpenoids were present in remarkable levels. The result also indicated that the species contained high levels of $\mathrm{K}$ and $\mathrm{Cl}$. The essential amino acids with the highest content. Thus, the overall study suggested that Gracilaria species could potentially be used as nutraceutical food. Further studies are planned to isolate, purify the major phytochemicals and its evaluation of biological potentialities.
\end{abstract}

Keywords: selective transfer, superficial layer, structural analysis, intensity x-rays, width of diffraction lines, crystalline network constant
Volume II Issue 2 - 2018

Sumayya SS,' Sreelekshmi SG, ${ }^{2}$ Murugan K 'Department of Botany, University College Thiruvananthapuram, India

${ }^{2}$ SCMS Institute of Bioscience and Biotechnology Research and Development, India

Correspondence: Murugan K, SCMS Institute of Bioscience and Biotechnology Research and Development, India, Email: harimurukan@gmail.com

Received: March 02, 2017 | Published: April 12, 2018

\section{Introduction}

Gracilaria species are important seaweeds of India harvested regularly from the coastal belts of India for the extraction of many pharmaceutically important products. Excessive exploitation led to the depletion of the natural biota in this area. Currently, methods of cultivation may pave the way to meet the demand of the industry. Macroalgae, belongs to agrophytes synthesize many biologically active secondary metbolites, which includes carotenoids, terpenoids, xanthophylls, chlorophylls, phycobilins, polyunsaturated fatty acids, polysaccharides, vitamins, sterols, tocopherol and phycocyanins. ${ }^{1}$ Seaweeds represent $23.4 \%$ of the tonnage and $9.7 \%$ of the value of the marine, brackish water, and freshwater aquaculture production, estimated at 59.4 million tonnes and $\$ 70.3$ billion in 2004. ${ }^{2,3}$ They are used as food, fodder, feed and fertilizer ${ }^{4}$ and many of the bioactive compounds produced by the macroalgae are known to have potential beneficial use in healthcare. ${ }^{5,6}$ Many mcroalgae in habitat in complex ecosystems exposed to adverse conditions and, in adapting to new environmental surroundings, they produce a wide variety of primary metabolites and phytochemicals which cannot be found in other plants. Marine-based bioactive molecules can be produced from a diverse sources, including marine plants, macro- and microalgae, microbes, and sponges, all of which contain their own unique set of biomolecules. Recently, Francavilla et al. ${ }^{7}$ found that Gracilaria species harvested may be used as an interesting source of natural porous material with several biotechnological applications. Further, Buldarin et al. ${ }^{8}$ found that microwave induced pyrolysis of this macroalga produced chemical rich bio-oils which are rich in aromatics, sugars and other high value chemicals. Polyphenolic compounds are usually found in edible brown, green and red seaweeds, whose antioxidant potentialities have been correlated to their phenolic contents. There are many reports on the antioxidant activities of steroids terpenoids and saponins. The antioxidant activity of polysaccharide from Bryopsis plumosa was reported by Song et al. ${ }^{9}$ Vinayak et al. ${ }^{10}$ reported cytotoxic and antioxidant activities of crude methanol extract of the brown seaweed Dictyopteris australis. In the scenario, nutraceutical, pharmaceutical and cosmetically important biomaterials to be screened. Thus, the present study aims to analyze the biochemical composition of Gracilaria corticata var. cylindrica and was collected from Thoothukudi in order to evaluate their biological importance.

\section{Materials and methods}

Fresh Gracilaria corticata var. cylindrica was collected from Thoothukudi.

\section{Proximate analysis}

Standard protocol of $\mathrm{AOAC}^{11}$ was employed to quantify the ash, lipid and moisture content of G. corticata var. cylindrica. The moisture content was determined by oven method at $105{ }^{\circ} \mathrm{C}$ until constant weight was attained. Crude protein content was analyzed by Lowry's method. ${ }^{12}$ Ash content was done by incinerating the algae in a muffle furnace at $550{ }^{\circ} \mathrm{C}$ for $16 \mathrm{~h}$ and the content was determined gravimetrically. Crude lipid was isolated from seaweed powder with chloroform: methanol $(2: 1, \mathrm{v} / \mathrm{v})$ in a Soxhlet extractor by the method of Bligh and Dryer ${ }^{13}$ The crude lipid content was measured gravimetrically after oven-drying $\left(80^{\circ} \mathrm{C}\right)$ the extract overnight. The total, soluble and insoluble dietary fiber contents were analyzed as per the enzymatic-gravimetric protocol. ${ }^{11}$

\section{Mineral analysis}

Elementary compositions of the sample was analyzed by atomic absorption spectrophotometry (AAS) for $\mathrm{Ca}, \mathrm{Mg}, \mathrm{K}$ and $\mathrm{Na}$ by 
inductively coupled plasma optical emission spectrometry for $\mathrm{Fe}, \mathrm{Cu}$ and $\mathrm{Zn},{ }^{11}$ gravimetric method for ${ }^{14}$ and chloride analyzer for $\mathrm{Cl}$.

\section{Amino acid analysis}

The samples were hydrolyzed with $6 \mathrm{~N} \mathrm{HCl}$ containing $1 \%$ phenol in a heating block at $110{ }^{\circ} \mathrm{C}$ for $24 \mathrm{~h}$ by high-performance liquid chromatography (HPLC) using the wave length of $250 \mathrm{~nm}$ and an emission wavelength of $395 \mathrm{~nm}$. Identification of the amino acids in the samples was carried out by comparison with retention times of the standards.

\section{Qualitative phytochemical analysis}

Preparation of plant extracts: $5 \mathrm{~g}$ of powdered material was subjected to hot continuous soxhlet extraction with different solvent such as petroleum ether, ethyl acetate, methanol and water for $8 \mathrm{~h}$. The extract was stored in a refrigerator and used for the present study. Qualitative phytochemical analysis was carried following the protocol of Kokate ${ }^{15}$ Alkaloids, carbohydrates, tannins and phenols, flavonoids, gums and mucilage, fixed oils and fats, saponins, pytosterol were qualitative analyzed.

\section{Polyphenol analysis}

The total phenolic content of algal extracts was assessed according to the Folin-Ciocalteu method. Gallic acid was used as a standard to construct the calibration curve $(20,40,60,80$ and $100 \mathrm{mg} \cdot \mathrm{L}-1)$. The total phenolic content of algal samples was expressed in $\mathrm{mg} \cdot \mathrm{g}-1$ of gallic acid equivalent (GAE).

Total flavonoid content was measured by the aluminum chloride colorimetric assay. ${ }^{16}$ An aliquot $(1 \mathrm{ml})$ of extracts and standard solution of catechin $(100 \mathrm{mg} / \mathrm{ml})$ was added to $10 \mathrm{ml}$ volumetric flask containing $4 \mathrm{ml}$ of distilled water. To this $0.3 \mathrm{ml} 5 \% \mathrm{NaNO} 2$ were added. After $5 \mathrm{~min}, 0.3 \mathrm{ml} 10 \% \mathrm{AlCl} 3$ was added. Then after $1 \mathrm{~min}, 2 \mathrm{ml}$ of $1 \mathrm{M} \mathrm{NaOH}$ was added and the total volume was made up to $10 \mathrm{ml}$ with distilled water. The solution was mixed well and the absorbance was measured against prepared reagent blank at $510 \mathrm{~nm}$. Total flavonoid content of root extracts expressed as mg catechin equivalents $(\mathrm{CE}) / 100 \mathrm{G}$ fresh weights. All samples were analyzed in triplicates.

About $10 \mathrm{~g}$ of powdered was taken and soaked in alcohol for 24 h. It was filtered and filtrate extracted with petroleum ether; this ether extract was treated as total terpenoids. ${ }^{17}$

\section{Statistical analysis}

All determinations were performed at least in triplicate. Statistical analysis was carried out by using the SPSS 10.0 version software for Windows. The analyzed data were expressed as mean with standard deviation (SD). Paired sample $t$-test was used to identify significant differences at $P<0.05$.

\section{Results and discussion}

\section{Proximal chemical composition}

The proximal composition of $G$. corticata var. cylindrica under present study reveals that the moisture content was $3.8 \%$ of the dry weight (DW). The protein content was $4.7 \mathrm{mg} / \mathrm{g}$ tissue $(P<0.05)$. Previous reports showed that the red and green seaweeds possess a protein content within the wide range $10-47 \%$ (DW). Similarly, Sargassum polycystum $(5.4 \% \mathrm{DW}),{ }^{18} \mathrm{G}$. domingensis $(6.2 \% \mathrm{DW})$ and
G. birdiae (7.1\% DW), Gelidium pristoides (11.8\% DW), ${ }_{19}^{19}$ Halymenia formosa $(21.2 \%),{ }^{20}$ G. cervicornis $(23.0 \% \mathrm{DW})^{21}$ and Grateloupia turuturu $\left(22.9 \%\right.$ DW), ${ }^{22}$ Porphyra tenera $(47 \%$ DW) and Palmaria palmata $(35 \% \mathrm{DW}) .{ }^{23}$ These levels varied depending on algal species, season and environment. ${ }^{24}$

The lipid content was $2.4 \%$ DW. The amount was comparable with the previous reports (1-3\% DW) (Fleurence, 1999), G. coronopifolia (2.1\%), G. salicornia (2.4\%), G. parvispora $(2.8 \% \mathrm{DW}),{ }^{20} G$. cervicornis $(0.43 \% \mathrm{DW})$ and Sargassum vulgare $(0.45 \%) .{ }^{21}$ The ash content was $18.6 \%$. The amounts of ash obtained in the present study was in agree- ment with the report of Ruperez and Saura-Calixto, ${ }^{26}$ Sánchez-Machado et al. ${ }^{27}$ G. domingensis $(23.8 \%$ DW), G. birdiae $(22.5 \%$ DW), Hypnea japonica $(22.1 \% \mathrm{DW})$ and H. charoides $(22.8 \% \mathrm{DW}){ }^{28}$ Generally, the ash contents in marine seaweeds are higher than terrestrial plants $(5-10 \%$ DW).The differences in ash contents depends up on physiology, environment, methodology and processing methods. ${ }^{26,29}$

Plant products contained large amounts of polysaccharides, which comprises high level of soluble and insoluble dietary fibers. ${ }^{30}$ In this study, the amounts of soluble, insoluble (SDF, IDF), and total dietary fibers was $13.6 \%, 37.9 \%$ and $61.4 \% \mathrm{DW}$, respectively. The content of total dietary fiber in seaweed was higher than those in terrestrial plants such as wheat $(44.5 \% \mathrm{DW})$, beans $(36.5 \% \mathrm{DW})$ and onions $(16.9 \%$ DW). ${ }^{31}$ In addition, the ratios of SDF/IDF was well balanced (close to $1: 2$ ) as the suggested by Figuerola et al..$^{32}$ Gracilaria species has SDF as sulphated galactans, which is regarded influential in slowing digestion and absorption of nutrients, as well as reducing levels of blood cholesterol and glucose. ${ }^{33}$ In contrast, IDF increases fecal bulk and decreases intestinal transit time. ${ }^{34}$ They have several beneficial physiological effects on humans in preventing constipation, colon cancer, cardiovascular disease and obesity. Therefore, G. corticata var. cylindrica may be alternatively used as raw materials for high fiber food production or as ingredients in food industry.

\section{Mineral contents}

The mean macro elements (Ca (225.3), P (300.2), K (7432), $\mathrm{Mg}(450), \mathrm{Na}(312)$ and $\mathrm{Cl}(1456)$ and trace elements $(\mathrm{Cu}(0.18)$ and $\mathrm{Zn}(0.83)$ contents ranged from $225.3-7432 \mathrm{mg} / 100 \mathrm{~g} \mathrm{DW}$ and $0.18-60.83 \mathrm{mg} / 100 \mathrm{~g} \mathrm{DW}$, respectively i.e., the seaweed species showed remarkable levels of $\mathrm{K}$ and $\mathrm{Cl}$ but poor in Na. Furthermore, their $\mathrm{Na} / \mathrm{K}$ ratio was low and therefore the seaweeds can help balance $\mathrm{Na} / \mathrm{K}$ ratio diets and reduce hypertension risk as described in the studies of the red and brown seaweeds by Rupérez. As for the trace elements, copper and zinc contents were found within small range and also below the maximum level allowed in seaweeds for human consumption in Japan and France $(10 \mathrm{mg} / 100 \mathrm{~g}){ }^{35}$

Thus, the present study suggests the possibility of using the seaweed species as food supplements to improve the nutritive value for the human diet and animal feed.

\section{Amino acid composition}

The essential amino acids (EAA) included are methionine, leucine, isoleucine, lysine, phenyl ala- nine, tyrosine, arginine, threonine and valine. However, the analytical method used could not determine tryptophan and cysteine. The levels of different essential amino acids ranged from 3.43 to $8.96 \mathrm{mg} / 100 \mathrm{mg}$ DW and sound levels of arginine (0.74), leucine (0.64) and threonine (0.57). Meanwhile, the non-EAA like aspartic acid (0.88), glutamic acid (0.62), serine (0.57), 
proline, glycine 0.61 ) and alanine $(0.59) \mathrm{mg} / 100 \mathrm{mg} \mathrm{DW}$. Aspartic and glutamic acids, which are responsible for the aroma and taste, are present in substantial levels.

\section{Qualitative analysis}

The different solvent extracts of the algae show presence of compound for carbohydrates, alkaloids, phenols, tannins, saponins and flavonoids. Methanol extract of the plant sample show these compounds at remarkable levels (Table 1).

\section{Phenols, flavonoids and terpenoid levels}

Total phenol content (TPC) was $23 \mathrm{mg} / \mathrm{g}$ GAE, flavonoids $8.2 \mathrm{mg} / \mathrm{g}$ and terpenoid $2.3 \mathrm{mg} / \mathrm{g}$. Different plants show diverse total phenolic contents and may be due to many influencing factors, such as algal species, geographical origin or the area of cultivation, seasonal, physiological, and environmental variations The proven sources of phenolic compounds, i.e., cocoa, red wine, and green tea constitute extraordinary exceptions; their phenolic contents of 611, 340 and 165 $\mathrm{mg} \cdot \mathrm{g}-1 \mathrm{GAE}$, respectively. Similarly, black tea (124mg $\cdot \mathrm{g}-1 \mathrm{GAE})$ had values comparable to the highest measured data. ${ }^{36}$ Generally, the phenolic contents in fresh algae was correlated with different extraction conditions used like ethanol extract of Eisenia bicyclis contained $319 \mathrm{mg} \cdot \mathrm{g}-1 \mathrm{GAE},{ }^{37}$ aqueous extract of Hizikia fusiformis $4.1 \mathrm{mg} \cdot \mathrm{g}-1 \mathrm{GAE},{ }^{38}$ methanol-chloroform extract of Laminaria japonica $0.3 \mathrm{mg} \cdot \mathrm{g}-1 \mathrm{GAE},{ }^{39}$ aqueous extract of Undaria pinnatifida $3.8 \mathrm{mg} \cdot \mathrm{g}-1 \mathrm{GAE},{ }^{40}$ ethanol extract of Palmaria palmata $10.3 \mathrm{mg} \cdot \mathrm{g}-1$ GAE, ${ }^{41}$ aqueous extract of Porphyra tenera $10.1 \mathrm{mg} \cdot \mathrm{g}-1 \mathrm{GAE}^{42}$ and Spirulina platensis $19.5 \mathrm{mg} \cdot \mathrm{g}-1$ GAE. ${ }^{43}$ The differences between phenolic contents could also be caused by the characteristics of the samples because all mentioned studies were realized with fresh algal samples contrary to the processed algal products analyzed in this work.

Table I Qualitative analysis of biological compounds in G. corticata var. cylindrical

\begin{tabular}{|c|c|c|c|c|c|}
\hline Compound Tested & Reagent's & Petroleum ether & Ethyl acetate & Methanol & Water \\
\hline \multirow[b]{2}{*}{ Carbohydrates } & Fehling's & - & - & + & + \\
\hline & Molish's & - & - & + & + \\
\hline \multirow{5}{*}{ Alkaloids } & Dragendraff's & + & + & - & - \\
\hline & Wagner's & + & + & - & - \\
\hline & & & & & \\
\hline & Hager's & + & + & - & - \\
\hline & Mayer's & + & + & - & - \\
\hline Tannins\& Phenols & $10 \%$ Lead acetate & + & + & +++ & ++ \\
\hline Flavonoids & $\mathrm{NaOH}+\mathrm{HCl}$ & + & + & ++ & + \\
\hline Gum \& Mucilage & $\begin{array}{l}\text { Alcoholic } \\
\text { Precipitation }\end{array}$ & - & + & - & - \\
\hline Fixed oils\& Fats & Spot Test & + & - & - & - \\
\hline Saponins & Foam Test & + & - & - & + \\
\hline Phytosterol & LB Test & + & - & - & - \\
\hline
\end{tabular}

\section{Conclusion}

The seaweed $G$. corticata var. cylindrica analyzed in this study had appreciable protein content, ash and dietary fiber, as well as minerals and essential amino acids. Therefore, the Gracilaria species appear to be potential sources or ingredients in functional food products and animal feed. Further studies are warranted to screen the secondary metabolites, its purification and evaluation of its biological potentialities.

\section{Acknowledgment}

None

\section{Conflict of interest}

Authors declare there is no conflict of interest towards this manuscript.

\section{References}

1. De Almeida CLF, de Falcão SH, de Lima MGR, et al. Bioactivities from marine algae of the genus Gracilaria. Int J Mol Sci. 12(7):4550-4573.

2. In Year Book of Fishery and Aquaculture Statistics. Food and Agricultural Organisation of the United Nations: Italy; 2006. p. 98

3. Bourgougnon N, Stiger-Pouvreau V. Red and brown Macroalgae along the French Coasts, Metropole and Overseas Departments and Territories. 1st ed. In Handbook of Marine Macroalgae, Biotech and Appl Phyco, SeKwon K, editor. New Delhi: JohnWiley \& Sons; 2012. p. 58-105.

4. Ghosh R, Banerjee K, Mitra A. Eco-Biochemical Studies of Common Seaweeds in the Lower Gangetic Delta. In Handbook of Marine Macroalgae: Biotechnology and Applied Phycology. 1st ed. Se-Kwon K, editor. John Wiley \& Sons, Ltd: New Delhi; 2012. P. 45-57.

5. Molinski TF, Dalisay DS, Lievens SL, et al. Drug development from marine natural products. Nat Rev Drug Discov. 2009;8(1):69-85. 
6. Lordan S, Ross RP, Stanton C. Marine bioactives as functional food ingredients: Potential to reduce the incidence of chronic diseases. Mar Drugs. 2011;9(6):1056-1100

7. Francavilla M, Pineda A, Lin CSK, et al. Natural porous agar materials from macroalgae. Carbohydr Polym. 2013;92(2):1555-1560.

8. Buldarin VL, Zhao Y, Gronnow MJ, et al. Microwave-mediated pyrolysis of macro-algae. Green Chem. 2011;13:2330-2333.

9. Song H, Zhang Q, Zhang Z, Wang J. In vitro antioxidant activity of polysaccharide extracted from Bryopsis plumose. Carbohyd Polym. 2010;80(4):1057-1061.

10. Vinayak CR, Sabu AS, Chatterji A. Bio-prospecting of a few Brown seaweeds for their cytotoxic and Antioxidant activities. Evid Based Complement Alternat Med. 2011;2011:673083.

11. AOAC. Official methods of analysis. 17th ed. Asso- ciation of Officia Analytical Chemists: Arlington VA; 2011. p. 98-112.

12. Lowry OH, Rosebrough NJ, Farr AL, et al. Protein measurement with the Folin phenol reagent. J Biol Chem. 1951;193(1):265-275.

13. Bligh EG, Dyer WJ. A rapid method of total lipid extraction and purification. Can J Biochem Physiol. 1959;37(8):911-917.

14. Kolthoff IM, Sandell EB, Meehan EJ, et al. Quantitative Chemical Analysis. Macmillan Company: New York; 1969.

15. Kokate CK. Practical pharmacognosy. 4th ed. Vallabh Prakan: New Delhi; 1994. p. 179-181.

16. Zhishen J, Mengcheng T, Jianming W. The determination of flavonoid contents in mulberry and their scavenging effects on superoxide radicals. Food Chem. 1999;64(4):555-559.

17. Ferguson NM. A Text book of Pharmacognosy. $2^{\text {nd }}$ ed. Mac Milan Company: New Delhi; 1956. p. 191.

18. Matanjun P, Mohamed S, Mustapha NM, et al. Nutrient content of tropical edible seaweeds, Eucheuma cottonii, Caulerpa lentillifera and Sargassum polycystum. J of Appl Phyco. 2009;21(1):75-80.

19. Foster GG, Hodgson AN. Consumption and apparent dry matter digestibility of six intertidal macroalgae by Turbo sarmaticus (Mollusca: Veti-gastropoda: Turbinidae). Aquaculture. 1998;167(3-4):211-277.

20. McDermid KJ, Stuercke B. Nutritional composi- tion of edible Hawaiian seaweeds. J Appl Phyco. 2003;15(6):513-524.

21. Marinho-Soriano E, Fonseca PC, Carneiro MAA. Et al. Seasonal variation in the chemical composition of two tropical seaweeds. Bioresource Techn. 2006;97(18):2402-2406.

22. Denis C, Morançais M, Li M, et al. Study of the chemical composition of edible red macroalgae Grateloupia turuturu from Brittany (France). Food Chem. 2010;119(3):913-917.

23. Fleurence J. Seaweed proteins: biochemical nutritional aspects and potential uses. Trends in Food Sci and Tech. 1999;10(1):25-28.

24. Ito K, Hori K. Seaweed: chemical composition and potential uses. Food Review International. 1989;5(1):101-144.

25. Rupérez P, Saura-Calixto F. Dietary fibre and phy-sicochemical properties of edible Spanish seaweeds. Eur Food Res Tech. 2001;212(3):349-354

26. Rupérez P. Mineral content of edible marine seaweeds. Food Chem 2002;79(1):23-26.
27. Sánchez-Machado DI, López-Hernández J, Paseiro- Losada P. Fatty acids, total lipid, protein and ash contents of processed edible seaweeds. Food Chem. 2004;85(3):439-444.

28. Wong K, Cheung PC. Nutritional evaluation of some subtropical red and green seaweeds. Part 1- proximate composition, amino acid profiles and some physico-chemical properties. Food Chem. 2001;71(4):75-482.

29. Nisizawa K, Noda H, Kikuchi R, et al. The main seaweed foods in Japan. Hydrobiologia. 1987;52:5-29.

30. Lahaye M. Marine algae as sources of fibers: Determi- nation of soluble and insoluble dietary fiber contents in some, sea vegetables. J of Sci and Food Agri. 1991;54(4):587-594.

31. Prosky L, Asp NG, Schweizer TF, et al. Determination of insoluble soluble dietary fiber in foods and food products: Collaborative study. J Assoc Off Anal Chem. 1988;71(5):1017-23.

32. Figuerola F, Hurtado ML, EstevezAM, et al. Fibre concentrates from apple pomace and citrus peel as potential fibre sources for food enrichment. Food Chem. 91(3):395-401.

33. Scheneeman BO. Soluble vs. insoluble fibre-different physiological responses. Food Tech. 1987;41:81-82.

34. Elleuch M, Bedigian D, Roiseux O, et al. Dietary fibre and fibre-rich by- products of food processing: Characterisation, tech- nological functionality and commercial applications: A review. Food Chem. 2011;124(2):411-421.

35. Indergaard M, Minsaas J. Animal and human nutrition. In Seaweed resources in Europe: uses and potential. MD Guiry G, Blunden, editors. John Wiley \& Sons Ltd: UK; 1991.p. 21-64.

36. Lee KW, Kim YJ, Lee HJ, et al. Cocoa has more phenolic phytochemicals and a higher antioxidant capacity than teas and red wine. J Agric Food Chem. 2003;51(25):7292-7295.

37. Kim SM, Kang K, Jeon JS, et al. Isolation of phlorotannins from Eisenia bicyclis and their hepatoprotective effects against oxidative stress induced by tert-butyl hyperoxide. Appl Biochem Biotechnol. 2011;165(56):1296-1307.

38. Heo SJ, Cha SH, Lee KW, et al. Antioxidant activities of chlorophyta and phaeophyta from Jeju Island. Algae. 2005;20(3):251-260.

39. Zhang WW, Duan XJ, Huang HL, Zhang Y, et al. Evaluation of 28 marine algae from the Qingdao coast for antioxidative capacity and determination of antioxidant efficiency and total phenolic content of fractions and subfractions derived from Symphyocladia latiuscula (Rhodomelaceae). J Appl Phycol. 2007;19(2):97-108.

40. Yuan YV, Bone DE, Carrington MF. Antioxidant activity of dulse (Palmaria palmata) extract evaluated in vitro. Food Chem. 2005;91(3):485-494.

41. Heo SJ, Cha SH, Lee KW, et al. Antioxidant activities of red algae from Jeju Island. Algae. 2006;21(1):149-156.

42. Liu JG, Hou CW, Lee SY, et al. Antioxidant effects and UVB protective activity of Spirulina (Arthrospira platensis) products fermented with lactic acid bacteria. Process Biochem. 46(6):1405-1410.

43. Li HB, Cheng KW, Wong CC, et al. Evaluation of antioxidant capacity and total phenolic content of different fractions of selected microalgae. Food Chem. 2007;102(3):771-776. 